\title{
Out of Pocket Payment
}

National Cancer Institute

\section{Source}

National Cancer Institute. Out of Pocket Payment. NCI Thesaurus. Code C148250.

A payment made from personal funds. 